hier in der angegebenen Weise zersetzt. Das am Ausgange der Röhre befindliche Jodkalium wird durch das Chlor und die Chlorwasserstoffsäure zerlegt und Jod frei gemacht, welches das Amylum des Papierstreifens sogleich blau färbt. Durch mehrfache Versuche wurde nachgewie-

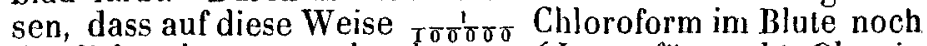
deutlich erkannt werden kann. (Journ. für pralit. Chemie. Bd. 46. p. 170.)

E. St.

\title{
Ein Reagens auf Proteinkörper.
}

E. Mill on wendet die Flüssigkeit, welche erhalten wird, wenn man metallisches Quecksilber in seinem gleichen Gewichte Salpetersäure von $4 \frac{1}{2}$ Aeq. Wassergehalt auflöst, als Reagens auf Proteinkörper an. (Schon in der Kälte geht die Auflösung des Quecksilbers vor sich, zuletzt unterstiutzt man sie durch vorsichtiges Erwärmen bis zur vollständigen Lösung. Einem Maass dieser Flüssigkeit setzt man 2 Maass Wasser zu, und nach einigen Stunden giesst man klar ab.) 1/100000 Eiweiss wird in seiner wässerigen Lösung durch die rothe Färbung bei Zusatz des genannten Reagens noch angezeigt. Die Reaction tritt schon bei gewöhnlicher Temperatur ein, beim Erhitzen auf $60-70^{\circ}$ ist sie aber vollkommen. Baumwolle, Stärke und Gummi färben sich auch rosenroth, der Harn färbt sich ebenso mit jener Fluissigkeit, nachdem der Harnstoff durch Erhitzen des Gemisches zerstört wurde. Das Eiweiss, das Fibrin, Casein, der Leim, das Legumin, die Seide, Wolle, Federn, Harn, Haut, Chondrin, Protein, Krystallin färben sich durch jene Flüssigkeit mehr oder minder roth. Auch wenn das Protein durch alkalische Laugen oder durch Schwefelsäure löslich geworden ist, entsteht die rothe Färbung noch, allein es entsteht dann kein Niederschlag mehr.

Die Xanthoproteinsäure, die Chlorproteinverbindungen und Proteinoxyde, die von den Chlorverbindungen abstammen, färben sich nicht mehr roth. Wenn Chlor auf Eiweiss so lange einwirkt, bis kein Gas mehr absorbirt wird, so entstehen drei verschiedene Substanzen, welche sich durch ihr Verhalten zu der genannten Probeflüssigkeit unterscheiden.

Bei der besprochenen Prüfungsfluissigkeit scheint die salpetrige Säure wesentlich, denn die rothe Färbung trut nicht ein bei Anwendung des salpetersauren Quecksilberoxyduls oder Oxyds, oder des Gemisches beider. (Compt.rend. Pharm. Centrbl. 1849. No. 12.) 